\title{
Forum
}

\section{Livestock as Ecosystem Engineers for Grassland Bird Habitat in the Western Great Plains of North America}

\author{
Justin D. Derner, ${ }^{1}$ William K. Lauenroth, ${ }^{2}$ Paul Stapp, ${ }^{3}$ and David J. Augustine ${ }^{4}$ \\ Authors are ${ }^{1}$ Rangeland Scientist, US Department of Agriculture (USDA)-Agricultural Research Service, High Plains Grasslands Research Station, 8408 \\ Hildreth Road, Cheyenne, WY 82009, USA; ${ }^{2}$ Professor, Department of Botany, University of Wyoming, Laramie, WY 82071, USA; ${ }^{3}$ Associate Professor, \\ Department of Biological Science, California State University, Fullerton, CA 92834, USA; and ${ }^{4}$ Ecologist, USDA-Agricultural Research Service, Crops \\ Research Laboratory, Fort Collins, CO 80526, USA.
}

\begin{abstract}
Domestic livestock have the potential to function as ecosystem engineers in semiarid rangelands, but prevailing management practices largely emphasize livestock production and uniform use of vegetation. As a result, variation in vegetation structure might not occur at appropriate spatial and temporal scales to achieve some contemporary conservation objectives. Here, we introduce the utility of livestock as ecosystem engineers and address potential benefits and consequences associated with heterogeneity-based management practices for conservation grazing in the semiarid rangelands of the western North American Great Plains. To illustrate the potential value of this approach, we provide specific examples where engineering effects of livestock could alter vegetation heterogeneity at within-pasture $(<100 \mathrm{ha})$ and among-pasture $(\sim 100$ ha to thousands of hectares) scales to improve habitat for declining native grassland birds. Experimental evaluations of the efficacy of livestock to achieve desired modifications to vegetation structure are needed, along with the economic aspects associated with implementing heterogeneity-based management practices. Using livestock as ecosystem engineers to alter vegetation structure for grassland bird habitat is feasible in terms of application by land managers within the context of current livestock operations, and provides land managers important tools to achieve desired contemporary objectives and outcomes in semiarid rangelands of the western North American Great Plains.
\end{abstract}

\section{Resumen}

El ganado domestico tiene el potencial de funcionar como ingeniero de los ecosistemas en los pastizales semiáridos, pero las practicas de manejo que existen principalmente se enfocan en la producción ganadera y el uso uniforme de la vegetación. Como resultado, la variación en la estructura de la vegetación puede no darse apropiadamente a escalas espaciales y temporales para llevar a cabo objetivos de conservación contemporáneos. Aquí, presentamos la utilidad del ganado como ingeniero de ecosistemas y en los beneficios y las consecuencias de la heterogeneidad basada en las prácticas de manejo para la conservación del pastoreo en los pastizales de las zonas semiáridas en el Oeste de las grandes planicies de Norte América. Para ilustrar el valor potencial de este método, proporcionamos ejemplos específicos donde los efectos de ingeniería del ganado domestico pueden alterar la heterogeneidad de la vegetación a escalas dentro $(<100 \mathrm{ha})$ y entre los potreros $(\sim 100-1000 \mathrm{~s}$ ha) para mejorar el hábitat de pastizales nativos que están disminuyendo para las aves. Evaluaciones experimentales de la eficiencia del ganado en la estructura de la vegetación son necesarias, de la misma manera los aspectos económicos asociados con la implementación de la practicas de manejo usadas para la heterogeneidad. El utilizar ganado como ingeniero de los ecosistemas para alterar la estructura de la vegetación para las aves del pastizal es posible en términos de aplicación por los manejadores de las tierras dentro del contexto de las actuales operaciones de ganado, permitiendo darles a los manejadores las herramientas para llevar a cabo los objetivos contemporáneos y resultados en los pastizales semiáridos de las grandes planicies de América del norte.

Key Words: community structure, conservation grazing, disturbances, patch burning, rangeland ecosystem, vegetation composition, vegetation heterogeneity, wildlife habitat

\section{INTRODUCTION}

One of the clearest, but least acknowledged, roles of domestic livestock in rangeland ecosystems is as ecosystem engineers (Jones et al. 1997), where livestock directly and indirectly influence the availability of resources to a wide range of

The USDA-ARS, Northern Plains Area, is an equal opportunity/affirmative action employer, and all agency services are available without discrimination.

Correspondence: Justin Derner, USDA-ARS, High Plains Grasslands Research Station, 8408 Hildreth Road, Cheyenne, WY 82009, USA. Email: Justin.Derner@ars.usda.gov

Manuscript received 14 January 2008; manuscript accepted 16 November 2008. organisms by inducing changes in vegetation structure. Prevailing rangeland management practices emphasizing even distribution of livestock use have decreased both temporal and spatial heterogeneity (hereafter referred to as only heterogeneity) of vegetation (Fuhlendorf and Engle 2001). Consequently, conflicts have increased between goals associated with traditional livestock production and contemporary conservation uses of semiarid rangelands (Knight et al. 2002). Scientists and managers in mesic rangeland ecosystems have evaluated land management practices that mimic historical disturbance regimes such as interactive effects of grazing and fire (Fuhlendorf and Engle 2001; du Toit et al. 2003) to produce a mosaic 


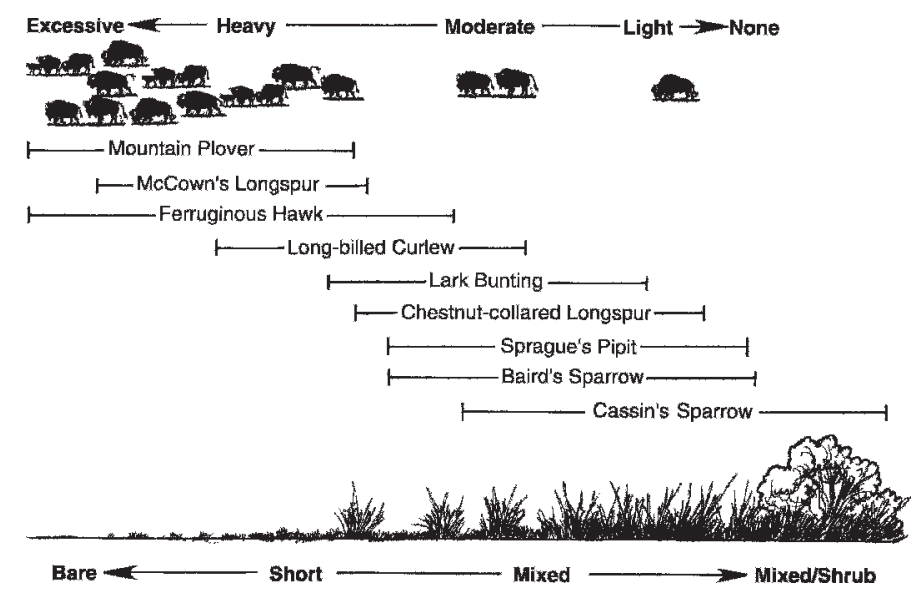

Figure 1. Responses of grassland birds in shortgrass steppe to a vegetation structure gradient (modified from Knopf 1996).

pattern of vegetation that provided habitat for a suite of species, while still maintaining livestock production (Fuhlendorf and Engle 2004; Fuhlendorf et al. 2006). Limited consideration has been given to management for vegetation heterogeneity in semiarid rangelands of the western North American Great Plains, and the ecological and economic aspects of modifying vegetation heterogeneity remain littlestudied (Hunt 2003).

Grazing has been demonstrated to influence vegetation structure in the Great Plains (Milchunas et al. 1988, 1989; Knopf 1996) as well as in other world rangelands (Sala et al. 1986; Fuls 1992; Hiernaux 1998; James et al. 1999; Hunt et al. 2007) and effects of grazing on spatial heterogeneity of vegetation have been recently reviewed (Adler et al. 2001; Parsons and Dumont 2003). Rangeland ecologists have recognized that livestock can create and maintain habitat for big game species in semiarid rangelands (Severson and Urness 1994) but livestock influences on habitat for grassland birds are not well understood. Widespread declines have occurred for many grassland birds of North America (Knopf 1992; Brennan and Kuvlesky 2005), including those in the western Great Plains (e.g., mountain plover [Charadrius montanus; Wiens and McIntyre 2008] and lesser prairie chicken [Tympanuchus pallidicinctus; US Fish and Wildlife Service 1998]). These declines have been hypothesized to be related to conversion of prairie to agriculture-dominated landscapes and prairie fragmentation (Knopf 1994), historic livestock grazing (Saab et al. 1995), and rangeland deterioration, including overgrazing, drought, lack of fire, and woody plant and exotic plant invasions (Brennan and Kuvlesky 2005). Although conversion of rangeland to cropland has likely been one factor driving grassland bird declines, this further emphasizes the need to effectively manage remaining rangelands in a manner that will sustain native species. Declining grassland bird populations might also be associated with livestock management methods that reduce variability in vegetation structure (Fig. 1), and hence reduce habitat for both grazing-intolerant and grazingdependent bird species (Saab et al. 1995). Historical interactions of large grazers, fire, drought, and prairie dogs (Cynomys spp.) created and maintained distinctly different plant communities in the western Great Plains resulting in a mosaic of vegetation structure and composition that sustained grassland bird populations (Brennan and Kuvlesky 2005). These interactions largely have been replaced by management practices that attempt to improve livestock distribution because uneven use of rangeland by livestock is a major problem for rangeland managers (Holechek et al. 1998). As a result, there is reason to believe that management practices that increase vegetation heterogeneity will be positive for grassland birds by increasing the variability in vegetation structure and/or composition. For example, the community of over 30 extant bird species that evolved within the western Great Plains (Knopf and Sampson 1996) requires a gradient of vegetation structure from relatively undisturbed, taller-structured vegetation to very short structure associated with fire or heavy use by large ungulates or blacktailed prairie dogs (Cynomys ludovicianus; Knopf 1996). Concerning the recent petition to list the lesser prairie chicken as threatened under the Endangered Species Act, the US Fish and Wildlife Service noted that "the Service believes that areas of heavily, moderately, and lightly grazed areas are necessary on a landscape scale" (US Fish and Wildlife Service 1998). Here, we examine how heterogeneity-based management practices, through the use of livestock as ecosystem engineers, can result in a mosaic of habitats differing in their structural complexity to address contemporary conservation goals for grassland birds in the western Great Plains.

We first provide background on the prior emphasis of uniform use of vegetation and subsequent reduction in heterogeneity of vegetation. Next, we address the biology for four grassland birds native to western Great Plains rangelands: 1) mountain plover, 2) long-billed curlew (Numenius americanus), 3) upland sandpiper (Bartramia longicauda), and 4) lesser prairie chicken. Habitat requirements of these four bird species for nesting and brood rearing are relatively well-known, and they collectively inhabit a gradient of vegetation structure. In addition, all four species are listed as "Birds of Conservation Concern" in the western Great Plains (US Fish and Wildlife Service 2002), and hence as priority species for conservation actions. Thirdly, we address potential benefits and consequences associated with heterogeneity-based management approaches for conservation grazing, and provide specific examples of where livestock might function as ecosystem engineers to alter heterogeneity of vegetation at within-pasture $(<100 \mathrm{ha})$ and among-pasture ( $\sim 100$ ha to thousands of hectares) scales.

\section{PRIOR MANAGEMENT EMPHASIS ON VEGETATION HOMOGENEITY}

Herbivores naturally select among plants in a pasture by eating preferred plants and ignoring others (Van Soest 1996), resulting in differential patterns of use of individual species within pastures (i.e., management units) when stocking rates are not excessive and pastures are of sufficient size (Launchbaugh and Howery 2005). Although the details of both forage plant and landscape selectivity have received considerable recent attention (Launchbaugh and Howery 2005), the view of livestock as ecosystem engineers that can alter the heterogeneity of vegetation is relatively new to rangeland managers. Most semiarid rangelands, however, have traditionally been managed for uniform use of vegetation and livestock production through implementation of growing-season grazing at a moderate 
intensity designed to utilize aboveground forage down to a particular amount, which maximizes livestock gains under the constraints of maintaining individual animal performance and preventing long-term ecosystem degradation (Bement 1969). This management practice has been very effective and sustainable from the standpoint of livestock and forage production (e.g., Hart and Ashby 1998), but the emphasis on homogeneity of use is counter to historic disturbance regimes (Fuhlendorf and Engle 2001). Widespread use of moderate grazing intensities has reduced availability of suitable habitat structure for many grassland birds at the extremes of the vegetation structure gradient (Fig. 1; Knopf 1996).

\section{ROLE OF LIVESTOCK MANAGEMENT IN PROMOTING DESIRABLE BIRD HABITAT}

Conflicts between interests of livestock producers and conservationists can be reduced if regionally appropriate grazing management strategies can be identified that use the engineering abilities of livestock to enhance grassland bird habitat. Below, we summarize the nesting and brood rearing habitats for each of four grassland bird species native to the western Great Plains (Table 1), as well as present potential management practices that incorporate livestock as ecosystem engineers to meet these habitat requirements. We use a simple approach to spatial scale by limiting our discussion to two scales: withinpasture $(<100 \mathrm{ha})$ and among-pasture $(\sim 100$ ha to thousands of hectares), because these spatial scales have relevance to land managers. We recognize that these two scales can be used individually or in combination, depending on the size of individual pastures and desired outputs.

\section{Mountain Plover}

The mountain plover winters in the Central and Imperial valleys of California, and migrates to the western Great Plains, arriving from mid-March to mid-April to nest (Dechant et al. 2003). Mountain plovers represent one extreme of the vegetation structure gradient (Fig. 1; Knopf 1996). Preferred habitats include flat topography on very heavily grazed sites, cultivated fields, recent burns, and prairie dog colonies, all of which have short vegetation and substantial amounts of bare ground (Knopf and Wunder 2006). They tend to shun sites with high plant cover or biomass (Table 1). Habitat requirements of mountain plovers are potentially in opposition to what has traditionally been considered good rangeland management practices in the shortgrass steppe (Bement 1969). Mountain plovers can both nest and rear broods in heavily disturbed rangeland, with estimates of home-range size for adults with broods of approximately 30-90 ha (Knopf and Rupert 1996).

Management practices of supplemental feed sites and patch burning can incorporate livestock as ecosystem engineers to alter vegetation structure at within-pasture scales for the mountain plover. Supplemental feed sites can be located strategically on flat topographical sites preferred by this species, and the combination of intense localized grazing and physical disturbance can increase bare ground and reduce vegetation cover (Fig. 2), as well as alter vegetation structure, but not alter arthropod and small mammal abundances (T. A. S. Newbold, unpublished data, 2004-2006). These supplemen- tal sites can be moved to different locations within and between years to prevent long-term degradation of the area. At the pasture scale, very heavy grazing intensities can be implemented in an attempt to reduce forage residue to very low levels and decrease vegetation structure, but these intensities result in substantially lowered animal performance (Bement 1969). Patch burning can be used successfully to create habitat conditions conducive to nesting mountain plovers (Fig. 2), with subsequent higher proportional use of these recently burned areas by livestock maintaining low vegetation structure (e.g., Vermeire et al. 2004). Heavy grazing and soil disturbance associated with the combination of black-tailed prairie dogs and livestock also provide breeding habitat for mountain plovers (Dinsmore et al. 2005; Tipton et al. 2008).

\section{Long-Billed Curlew}

The long-billed curlew is unique among the large-bodied avian species in its use of low-stature and recently disturbed rangeland for nesting (reviewed by Paton and Dalton 1994) and its reliance on resemblance to bovid fecal piles for concealment (King 1978). In the Great Plains, the breeding distribution of long-billed curlews is strongly clustered in northwestern Nebraska, and in the region immediately surrounding the confluence of Colorado, New Mexico, Oklahoma, and Texas (Sauer et al. 2005; Sparks and Hanni 2006). These areas contain include a patchwork of lightly to heavily grazed rangelands, irrigated and dryland agricultural fields, and tall-structure vegetation in formerly cropped lands that have been restored. Long-billed curlews in shortgrass steppe of southeastern Colorado can nest in extremely short vegetation (Fig. 2) associated with recent burns, heavy grazing, or prairie dog colonies. In contrast, adults with broods increase use of midheight $(20-50 \mathrm{~cm})$ rangeland and areas with a mosaic of short $(<10 \mathrm{~cm})$ to midheight $(10-40 \mathrm{~cm})$ grasses (Fig. 2; King 1978). Similarly, long-billed curlews with chicks in northern mixed-grass prairie were reported in grass that was $18 \mathrm{~cm}$ tall (Spomer 1981 as cited in Dechant et al. 2002). The limited available information on spatial ecology of this species suggests an association with vegetation heterogeneity both at the within- and among-pasture scales. For example, withinpasture scale heterogeneity can result from variation across a gradient from heavily grazed areas near water to more distant, lightly grazed areas. Similarly, among-pasture scale heterogeneity can encompass vegetative boundaries found at pasture edges that can be attributable to different timing and/or intensity of grazing in adjacent pastures.

Management practices at both the within-pasture and among-pasture scales can incorporate livestock as ecosystem engineers to alter vegetation structure for the long-billed curlew. As described previously, both supplemental feed and patch burning with subsequent grazing can create low structure and recently disturbed areas for nesting. In addition, both practices can provide areas of taller structure within the same pasture by proportionally increasing grazing pressure at the area of interest, and reducing grazing pressure at other locations in the pasture to increase within-pasture heterogeneity (Fuhlendorf et al. 2006). If pastures are of sufficient size such that areas in the pasture are $>2 \mathrm{~km}$ from a water source, a gradient of very heavy use (around water) to light or no use 


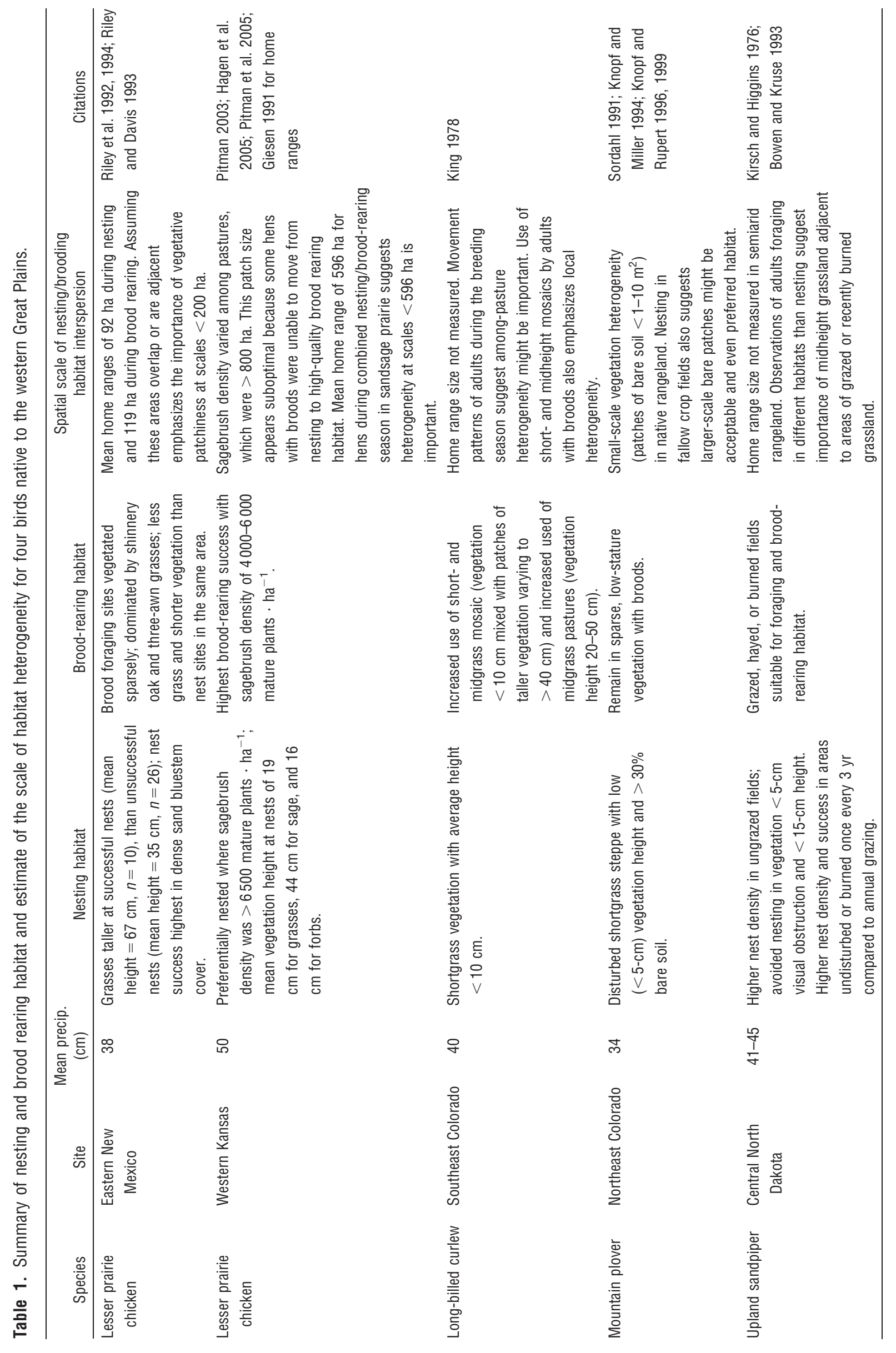




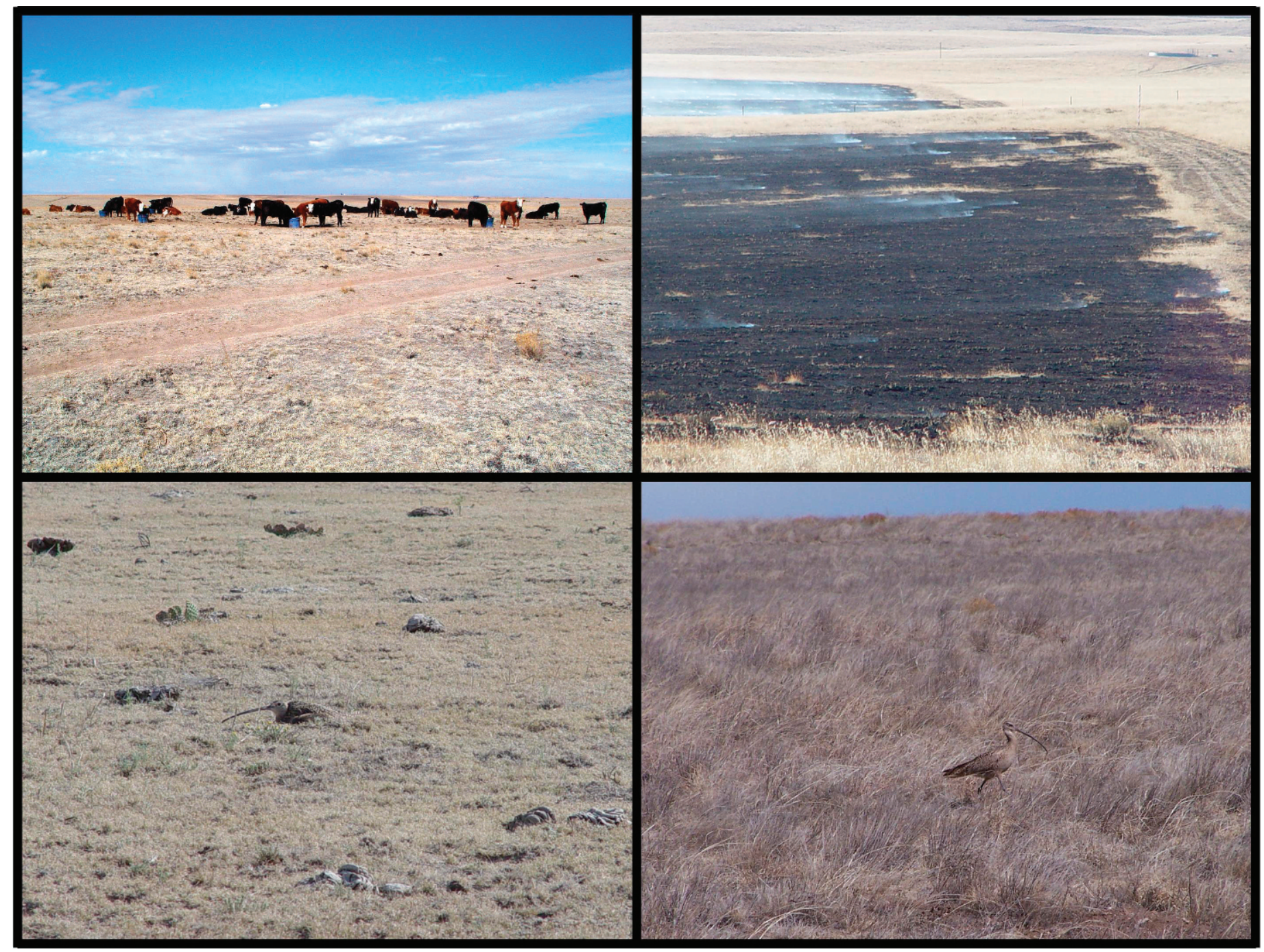

Figure 2. Example of within-pasture scale heterogeneity management through modifying livestock behavior by (upper left) strategic placement of supplemental feed (photo credit: Mary Ashby); (upper right) example of within-pasture scale heterogeneity management through patch burning in shortgrass steppe (photo credit: Mary Ashby); and (bottom left) examples of nesting habitat (photo credit: David Augustine) of long-billed curlew with low vegetation structure and prevalence of bovid fecal piles for concealment, and (bottom right) foraging habitat (photo credit: Cedric Selby) in midheight grassland.

(area furthest from water) can result (e.g., Adler and Hall 2005), commonly called the piosphere effect (Lange 1969), and provide a suite of needed habitats for this species. At the among-pasture scale, varying intensities and/or seasons of use, including deferment and/or rest might be sufficient to create differences in vegetation structure between pastures, thereby increasing edge effects.

\section{Lesser Prairie Chicken and Upland Sandpiper}

Both the lesser prairie chicken and the upland sandpiper rely on concealment in taller structure vegetation for nesting in semiarid rangelands (Table 1). The lesser prairie chicken primarily occurred in the semiarid, southern Great Plains prior to European settlement (Johnsgard and Wood 1968) and is associated with plant communities on sandy soils with an unpalatable shrub component such as sand sagebrush (Artemisia filifolia Torr.) or shinnery oak (Quercus havardii Rydb.; Robb and Schroeder 2005). In contrast, the upland sandpiper has a broad distribution that extends beyond central North America, but historically occurred throughout the semiarid northern Great Plains (Houston and Bowen 2001). In semiarid rangeland, upland sandpipers preferentially nest in areas with light or no cattle grazing during the spring and early summer, even though they often forage, raise broods, and are observed in moderately to heavily grazed pastures (Kirsch and Higgins 1976; Bowen and Kruse 1993). Lesser prairie chickens often preferentially nest in the tallest and most dense vegetation available in the landscape (Giesen 1991; Riley et al. 1992; Pitman et al. 2005), but optimal brood-rearing habitat contains less dense vegetation with lower shrub and grass cover, and greater invertebrate biomass (Jones 1963; Riley and Davis 1993; Hagen et al. 2005).

The dependence of lesser prairie chickens and upland sandpipers on tall-structure vegetation for nesting indicates a need for patches that have either been ungrazed or lightly grazed during the preceding growing season. Yet, Jones (1963) concluded that lesser prairie chicken habitat generally consists 
of small patches of short grass interspersed with large patches of shrub or half-shrub vegetation. In addition, chick growth of prairie chickens and upland sandpipers is dependent upon the arthropod supply (Houston and Bowen 2001), which is less abundant in undisturbed vegetation, and increases with recent grazing or fire disturbance (Joern 2004). Thus, these native grassland birds appear to depend upon a shifting mosaic of recently disturbed and undisturbed patches across the landscape. Large, uniform areas of taller-structure vegetation might prevent broods from reaching patches with vegetation structure conducive to their movement (Jones 1963; Hagen et al. 2004). Rest-rotation grazing systems, where at least one pasture remains ungrazed each year, can be an effective among-pasture scale approach to sufficiently modify vegetation structure and provide necessary nesting habitat for these grassland bird species (Bowen and Kruse 1993; Hagen et al. 2004). The same accumulation of residual vegetation that provides nesting concealment the following spring can begin to reduce broodrearing habitat quality and insect availability in subsequent years. As a result, long-term grazing exclusion can be as detrimental to habitat quality as continuous grazing pressure. For a multipasture rotation with moderate stocking rates, shifting from a system where each pasture is utilized equally over the grazing season to a system where some pastures are grazed more intensively and other pastures are either rested or grazed lightly could increase both within-pasture and amongpasture scale variability in vegetation structure. Rotation of grazing intensity among pastures over annual time scales can prevent any one patch or pasture within the landscape from experiencing long-term degradation.

\section{UTILITY OF LIVESTOCK AS ECOSYSTEM ENGINEERS: POTENTIAL BENEFITS AND CONSEQUENCES}

Livestock grazing behavior can be modified through location of supplemental feed, water, and herding (e.g., Bailey 2005). As a result, creating mosaics of vegetation patches and increasing structural diversity of vegetation can be accomplished (Vavra 2005). Livestock have the potential to function as ecosystem engineers, but there remain unanswered questions regarding potential benefits and consequences associated with heterogeneity-based management practices.

The within-pasture scale approach minimizes negative ecological impacts to the entire pasture. Localized disturbances (i.e., patches) are created in which vegetation structure is altered in an appropriate time frame for the desired goal. Three within-pasture scale strategies with potential for widespread application in semiarid rangelands of the western Great Plains are use of supplemental feed, the implementation of patch burns, and the manipulation of multiple water sources within a pasture (Bailey 2005). Salt placement is also often discussed as a way to alter livestock distribution (Williams 1954), but salt locations only have a minor influence of grazing distribution over a growing season (Ganskopp 2001). Strategic placement of supplemental feed (Bailey and Welling 1999; Bailey et al. 2001) can reduce vegetation structure in a given patch (Fig. 2) in a pasture, and this disturbance can be shifted temporally and spatially to achieve desired goals and prevent long-term ecosystem degradation. Manipulation of water sources can be used in a similar manner as supplemental feed (Williams 1954; Ganskopp 2001) but this strategy requires availability or installation of multiple tank locations and can be less flexible for rotating areas of intensive grazing disturbance over time. In the case of patch burning, a portion of a pasture can be burned in an effort to restore a shifting mosaic of vegetation patterns (e.g., Fuhlendorf and Engle 2004; Fig. 2). Burned areas of a pasture receive greater grazing pressure because cattle prefer green nutritious regrowth, and unburned areas receive proportionately less use, resulting in an accumulation of standing crop in some areas (Fuhlendorf and Engle 2001, 2004).

The among-pasture scale heterogeneity approach differs from the within-pasture scale approach in that the disturbance is applied to the entire pasture, with the overriding goal of creating substantial differences in vegetation structure among pastures within a larger management unit, at the scale of hundreds to thousands of hectares or square kilometers (e.g., ranch, allotment). Thus, the approach would be to vary grazing intensities (none, light, moderate, heavy, very heavy), seasons (winter, spring, summer, fall), and/or grazing animals (sheep, goats, cattle, or some combination) among pastures to alter the structure of vegetation within a given pasture. Burning of an entire pasture will not increase vegetation heterogeneity within the pasture, but if the burned pasture is part of a larger management unit, then among-pasture differences can be enhanced. Pasture-scale heterogeneity approaches also can take advantage of naturally-occurring variability among pastures due to differences in topo-edaphic conditions (e.g., lowlands vs. uplands), presence/absence of prairie dogs, and season of use (e.g., spring vs. summer grazing).

A benefit of altering within-pasture scale heterogeneity is minimizing negative ecological consequences over the entire pasture by localizing impacts spatially to targeted locations (e.g., supplemental feed sites, patch burn areas) and temporally because these patches can be moved within a pasture each year. In contrast, among-pasture scale heterogeneity has the benefit that this is typically the management unit for land managers. As such, managers are likely more comfortable in modifying management practices within the confines of existing infrastructure limitations (e.g., fences) compared to intensifying management within pastures to create smaller patches of heterogeneity.

\section{MANAGEMENT IMPLICATIONS}

Traditional emphasis on homogeneous use of vegetation (i.e., "management to the middle") at the pasture scale has resulted in the lack of suitable habitat for grassland birds at the extremes of the vegetation structure gradient in semiarid rangelands (Fig. 1). Therefore, use of livestock as ecosystem engineers has substantial potential to alter vegetation structure, primarily at the extremes of the structure gradient. Numerous studies have documented responses of grassland birds to varying grazing intensities (Saab et al. 1995), and the importance of vegetation heterogeneity for semiarid rangeland birds has been recognized for at least four decades (Jones 1963), but development and application of rangeland management practices to maintain or enhance vegetation heterogeneity 
remains a need. Incorporating livestock as ecosystem engineers to create an array of habitats, therefore, has utility for addressing the interface of production and conservation goals for land managers. Unfortunately, few experiments have quantified the economic costs of heterogeneity-based management in semiarid rangelands (Hunt 2003). There is an emergent need to determine these costs in relation to the traditional management approaches to determine the practicality of landowners modifying management practices, and if incentive programs might be needed to facilitate the implementation of heterogeneity-based management to achieve both production and conservation goals. Another limitation in the application of livestock as ecosystem engineers for enhancing habitats for grassland birds is the paucity of information on the optimal size, distribution, and juxtaposition of habitat patches for individual species across the landscape. Also, most land managers commonly apply rangeland management practices at the pasture scale, indicating that there might be some discomfort in applying heterogeneity-based management practices within pastures to create this scale of vegetation heterogeneity. The fact that many grassland birds require a mosaic of habitat patches to complete their breeding requirements (Table 1), however, suggests that within-pasture scale management might often be appropriate, and that mechanisms (e.g., incentives) should be considered to promote these approaches.

Approaches using livestock as ecosystem engineers to alter vegetation structure provide an alternative to complete cessation of livestock grazing on public lands as called for by Fleischner (1994) and Donahue (1999). The heterogeneitybased management practices are feasible in terms of application by land managers within the context of current livestock operations. The ecological and economic aspects of using livestock as ecosystem engineers to provide appropriate habitat through heterogeneity-based management for grassland birds such as the mountain plover merit additional research. Using livestock as ecosystem engineers to achieve conservation grazing objectives and outcomes in semiarid rangelands of the western Great Plains provides land managers with the opportunity to reduce conflicts between conservation and livestock production goals on these lands.

\section{ACKNOWLEDGMENTS}

We thank the Shortgrass Steppe Long-Term Ecological Research project for support (National Science Foundation Grant DEB-0217631). We thank David Engle, Chad Boyd, Tom Thurow, and two anonymous reviewers, as well as Associate Editor Leigh Hunt for helpful comments on a previous version of the manuscript.

\section{LITERATURE CITED}

Adler, P. B., And S. A. Hall. 2005. The development of forage production and utilization gradients around livestock watering points. Landscape Ecology 20:319-333.

Adler, P. B., D. A. Raff, and W. K. Lauenroth. 2001. The effect of grazing on the spatial heterogeneity of vegetation. Oecologia 128:465-479.

BAlley, D. W. 2005. Identification and creation of optimum habitat conditions for livestock. Rangeland Ecology and Management 58:109-118.
Balley, D. W., and G. R. Welling. 1999. Modification of cattle grazing distribution with dehydrated molasses supplement. Journal of Range Management 52:575-582.

Bailey, D. W., G. R. Welling, and E. T. Miller. 2001. Cattle use of foothills rangeland near dehydrated molasses supplement. Journal of Range Management 54:338-347.

BEMENT, R. E. 1969. A stocking rate guide for beef production on blue grama range. Journal of Range Management 22:83-86.

Bowen, B. S., And A. D. Kruse. 1993. Effects of grazing on nesting by upland sandpipers in southcentral North Dakota. Journal of Wildlife Management 57:291-301.

Brennan, L. A., And W. P. Kuvlesky, JR. 2005. North American grassland birds: an unfolding conservation crisis? Journal of Wildlife Management 69:1-13.

Dechant, J. A., M. L. Sonderal, D. H. Johnson, L. D. Igl, C. M. Goldade, M. P. Nenneman, and B. R. Euliss. 2003. Effects of management practices on grassland birds: mountain plover. Jamestown, ND, USA: Northern Prairie Wildlife Research Center. Available at: http: //www.npwrc.usgs.gov/resource/ literatr/grasbird/mopl/mopl.htm. Accessed 18 December 2004.

Dechant, J. A., M. L. Sondreal, D. H. Johnson, L. D. Igl, C. M. Goldade, P. A. Rabie, AND B. R. EuLISS. 1999 (revised 2002). Effects of management practices on grassland birds: long-billed curlew. Jamestown, ND, USA: Northern Prairie Wildlife Research Center. $19 p$.

Dinsmore, S. J., G. C. White, and F. L. Knopf. 2005. Mountain plover population responses to black-tailed prairie dogs in Montana. Journal of Wildlife Management 69:1546-1553.

DonahuE, D. L. 1999. The western range revisited: removing livestock from public lands to conserve native biodiversity. Norman, OK, USA: University of Oklahoma Press. 388 p.

Du Tolt, J. T., K. H. Rogers, and H. C. Biggs. 2003. The Kruger experience: ecology and management of savanna heterogeneity. Washington, DC, USA: Island Press. 519 p.

Fleischner, T. L. 1994. Ecological costs of livestock grazing in western North America. Conservation Biology 8:629-644.

Fuhlendorf, S. D., AND D. M. Engle. 2001. Restoring heterogeneity on rangelands: ecosystem management based on evolutionary grazing patterns. BioScience 51:625-632.

Fumlendorf, S. D., And D. M. Engle. 2004. Application of the fire-grazing interaction to restore a shifting mosaic on tallgrass prairie. Journal of Applied Ecology 41:604-614.

Fuhlendorf, S. D., W. C. Harrell, D. M. Engle, R. G. Hamilton, C. A. Davis, and D. M. LESLIE, JR. 2006. Should heterogeneity be the basis for conservation? Grassland bird response to fire and grazing. Ecological Applications 16:1706-1716.

FuLs, E. R. 1992. Ecosystem modification created by patch-overgrazing in semiarid grassland. Journal of Arid Environments 23:59-69.

GanSKOPP, D. 2001. Manipulating cattle distribution with salt and water in large arid-land pastures: a GPS/GIS assessment. Applied Animal Behavior Science 73:251-262.

GIESEN, K. M. 1991. Population inventory and habitat use by lesser prairie-chickens in southeast Colorado. Federal Aid in Wildlife Restoration Report, W-152-R. Fort Collins, CO, USA: Colorado Division of Wildlife. 29 p.

Hagen, C. A., B. E. Jamison, M. Kenneth, K. M. Giesen, and T. Z. Riley. 2004. Guidelines for managing lesser prairie-chicken populations and their habitats. Wildlife Society Bulletin 32:69-82.

Hagen, C. A., G. C. Salter, J. C. Pitman, R. J. Robel, and R. D. Applegate. 2005. Lesser prairie-chicken brood habitat in sand sagebrush: invertebrate biomass and vegetation. Wildlife Society Bulletin 33:1080-1091.

HaRt, R. H., And M. M. Ashby. 1998. Grazing intensities, vegetation and heifer gains: 55 years on shortgrass. Journal of Range Management 51:392398.

Hiernaux, P. 1998. Effects of grazing on plant species composition and spatial distribution in rangelands of the Sahel. Plant Ecology 138:191-202.

Holechek, J. L., R. D. Pieper, and C. H. Herbel. 1998. Range management: principles and practices. 3rd ed. Upper Saddle River, NJ, USA: Prentice-Hall. $542 \mathrm{p}$. 
Houston, C. S., and D. E. Bowen, JR. 2001. Upland sandpiper (Bartramia longicauda). In: A. Poole [ED.]. The birds of North America online. Ithaca, NY, USA: Cornell Lab of Ornithology. Available at: http://bna.birds.cornell.edu/ bna/species/580. Accessed 12 January 2008.

Hunt, L. P. 2003. Opportunities for the future in Australia's grazed rangelands. The Rangeland Journal 25:183-195.

Hunt, L. P., S. Petty, R. Cowley, A. Fisher, A. J. Ash, and N. MacDonald. 2007. Factors affecting the management of cattle grazing distribution in northern Australia: preliminary observations on the effect of paddock size and water points. The Rangeland Journal 29:169-179.

James, C. D., J. Landsberg, and S. R. Morton. 1999. Provision of watering points in the Australian arid zone: a review of effects on biota. Journal of Arid Environments 41:87-121.

Joern, A. 2004. Variation in grasshopper (Acrididae) densities in response to fire frequency and bison grazing in tallgrass prairie. Environmental Entomology 33:1617-1625.

Johnsgard, P. A., and R. E. Wood. 1968. Distributional changes and interaction between prairie chickens and sharp-tailed grouse in the midwest. Wilson Bulletin 80:173-188.

Jones, C. G., J. H. LaWton, and M. Shachak. 1997. Positive and negative effects of organisms as ecosystem engineers. Ecology 78:1946-1957.

JoNES, R. E. 1963. Identification and analysis of lesser and greater prairie chicken habitat. Journal of Wildlife Management 27:757-777.

KING, R. 1978. Habitat use and related behaviors of breeding long-billed curlews [thesis]. Fort Collins, CO, USA: Colorado State University. 69 p.

KIRSCH, L. M., AND K. F. HIGGINS. 1976. Upland sandpiper nesting and management in North Dakota. Wildlife Society Bulletin 4:16-20.

Knight, R. L., W. C. Gilgert, and E. Marston [eds.]. 2002. Ranching west of the 100th meridian. Washington, DC, USA: Island Press. 259 p.

Knopf, F. L. 1992. Faunal mixing, faunal integrity, and the biopolitical template for diversity conservation. Transactions of the North American Wildlife Natural Resources Conference 57:330-342.

Knopf, F. L. 1994. Avian assemblages on altered grasslands. Studies in Avian Biology 15:247-257

Knopf, F. L. 1996. Prairie legacies—birds. In: F. B. Samson and F. L. Knopf [eds.]. Prairie conservation: preserving North America's most endangered ecosystem. Washington, DC, USA: Island Press. p. 135-148.

Knopf, F. L., AND B. J. MıLler. 1994. Charadrius montanus—montane, grassland, or bare-ground plover? Auk 111:504-506.

Knopf, F. L., and J. R. Rupert. 1996. Productivity and movements of mountain plovers breeding in Colorado. Wilson Bulletin 108:28-35.

Knopf, F. L., AND J. R. Rupert. 1999. Use of cultivated fields by breeding Mountain Plovers in Colorado. Studies in Avian Biology 19:81-86.

Knopf, F. L., And F. B. Samson. 1996. Conserving the biotic integrity of the Great Plains. In: S. R. Johnson and A. Bouzaher [EDs.]. Conservation of Great Plains ecosystems. Boston, MA, USA: Kluwer Academic Publishers. p. 121-123.

Knopf, F. L., AND M. A. Wunder. 2006. Mountain plover (Charadrius montanus). In: A. Poole [ED.]. The birds of North America online. Ithaca, NY, USA: Cornell Lab of Ornithology. Available at: http://bna.birds.cornell.edu/bna/species/211. Accessed 12 January 2008.

Lange, R. T. 1969. The piosphere: sheep track and dung patterns. Journal of Range Management 22:396-400.

Launchbaugh, K. L., and L. D. Howery. 2005. Understanding landscape use patterns of livestock as a consequence of foraging behavior. Rangeland Ecology and Management 58:99-108.

Milchunas, D. G., W. K. Lauenroth, P. L. Chapman, and M. K. Kazenpour. 1989. Effects of grazing, topography, and precipitation on the structure of a semiarid grassland. Vegetatio 80:11-23.

Milchunas, D. G., O. E. Sala, and W. K. Lauenroth. 1988. A generalized model of the effects of grazing by large herbivores on grassland community structure. American Naturalist 132:87-106.

Parsons, A. J., and B. Dumont. 2003. Spatial heterogeneity and grazing processes. Animal Research 52:161-179.

Paton, P. W. C., and J. Dalton. 1994. Breeding ecology of long-billed curlews at Great Salt Lake, Utah. Great Basin Naturalist 51:79-85.
Pitman, J. C. 2003. Lesser prairie-chicken nest site selection and nest success, juvenile gender determination and growth, and juvenile survival and dispersal in southwestern Kansas [thesis]. Manhattan, KS, USA: Kansas State University. $169 \mathrm{p}$.

Pitman, J. C., C. A. Hagen, R. J. Robel, T. M. Loughin, and R. D. Applegate. 2005. Location and success of lesser prairie-chicken nests in relation to vegetation and human disturbance. Journal of Wildlife Management 69:1259-1269.

Riley, T. Z., and C. A. Davis. 1993. Vegetative characteristics of lesser prairiechicken brood foraging sites. Prairie Naturalist 25:243-248.

Riley, T. Z., C. A. Davis, M. A. Canderlaria, and H. R. Suminski. 1994. Lesser prairiechicken movements and home ranges in New Mexico. Prairie Naturalist 26:183-186.

Riley, T. Z., C. A. Davis, M. Ortiz, and M. J. Wisdom. 1992. Vegetative characteristics of successful and unsuccessful nests of lesser prairiechickens. Journal of Wildlife Management 56:383-387.

RobB, L. A., And M. A. Schroeder. 2005. Lesser prairie-chicken (Tympanuchus pallidicinctus): a technical conservation assessment. Available at: http://www. fs.fed.us/r2/projects/scp/assessments/lesserprairiechicken.pdf. Accessed 12 January 2008.

SaAb, V. A., C. E. Bock, T. D. Rich, and D. S. Dobkin. 1995. Livestock grazing effects in western North America. In: T. E. Martin and D. M. Finch [EDS.]. Ecology and management of Neotropical migratory birds: a synthesis and review of critical issues. New York, NY, USA: Oxford University Press. p. 311-353.

Sala, 0. E., M. Oesterheld, R. J. C. Leon, and A. Soriano. 1986. Grazing effects upon plant community structure in subhumid grasslands of Argentina. Vegetatio 67:27-32.

Sauer, J. R., J. E. Hines, and J. Fallon. 2005. The North American breeding bird survey, results and analysis 1966-2005. Version 6.2.2006. Laurel, Maryland, USA: USGS Patuxent Wildlife Research Center. Available at: http://www. mbr-pwrc.usgs.gov/bbs/. Accessed 12 January 2008.

Severson, K. E., AND P. J. URness. 1994. Livestock grazing: a tool to improve wildlife habitat. In: M. Vavra, W. A. Laycock, and R. D. Pieper [EDS.]. Ecological implications of livestock herbivory in the west. Denver, CO, USA: Society for Range Management. p. 232-249.

SoRdahl, T. A. 1991. Antipredator behavior of mountain plover chicks. Prairie Naturalist 23:109-115.

Sparks, R., and D. Hannl. 2006. Section-based monitoring of breeding birds within the shortgrass prairie bird conservation region (BCR 18). Brighton, CO, USA: Rocky Mountain Bird Observatory. Available at: http://www.rmbo.org/pubs/ default.html\#reports. Accessed 10 January 2008.

Spomer, R. 1981. Long-billed curlews and Sprague's pipits near Pierre. South Dakota Bird Notes 33:78.

Tipton, H. C., V. J. Dreitz, and P. F. DoherTy. 2008. Occupancy of mountain plover and burrowing owl in Colorado. Journal of Wildlife Management 72:10011006.

US FISH AND WILDLIFE SERVICE. 1998. Endangered and threatened wildlife and plants; 12-mo finding for a petition to list the lesser prairie-chicken as threatened and designate critical habitat. Washington, DC, USA: Federal Register 50 CFR Part 17, 63:31400-31406.

US Fish ANd Wildolfe Service. 2002. Birds of conservation concern 2002. Arlington, VA, USA: Division of Migratory Bird Management. 99 p. (Online version available at: http://migratorybirds.fws.gov/reports/bcc2002.pdf.)

Van Soest, P. J. 1996. Allometry and ecology of feeding behavior and digestive capacity in herbivores: a review. Zoo Biology 15:455-479.

VAVRA, M. 2005. Livestock grazing and wildlife: developing compatibilities. Rangeland Ecology and Management 58:128-134.

Vermeire, L. T., R. B. Mitchell, S. D. Fuhlendorf, and R. L. Gillen. 2004. Patch burning effects on grazing distribution. Journal of Range Management $57: 248-252$

Wiens, J. A., and N. E. Mclntyre. 2008. Birds of the shortgrass steppe. In: W. K. Lauenroth and I. C. Burke [EDS.]. Ecology of the shortgrass steppe: a long-term perspective. New York, NY, USA: Oxford University Press. p. 270-305.

WiLlıams, R. E. 1954. Modern methods of getting uniform use of ranges. Journal of Range Management 7:77-81. 